\title{
Liberating Hollywood
}





\section{Liberating Hollywood}

WOMEN DIRECTORS AND THE

FEMINIST REFORM OF $1970 \mathrm{~S}$

AMERICAN CINEMA

米

Maya Montañez Smukler

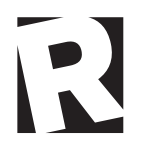

RUTGERS UNIVERSITY PRESS

New Brunswick, Camden, and Newark, New Jersey, and London 
Library of Congress Cataloging-in-Publication Data

Names: Smukler, Maya Montanez, author.

Title: Liberating Hollywood : women directors and the feminist reform of 1970 s

American cinema / Maya Montanez Smukler.

Description: New Brunswick, New Jersey : Rutgers University Press, [2018] | Includes bibliographical references and index.

Identifiers: LCCN 2018018808| ISBN 9780813587486 (cloth) | ISBN 9780813587479 (pbk.)

Subjects: LCSH: Women motion picture producers and directors-United States. Women in the motion picture industry-United States-History-2oth century. | Feminist films-United States-History and criticism. | Feminism and motion pictures.

Classification: LCC PN1995.9.W6 S638 2018 | DDC 791.43/6522-dc23

LC record available at https://lccn.loc.gov/2018018808

A British Cataloging-in-Publication record for this book is available from the British Library.

Copyright $\odot 2019$ by Maya Montañez Smukler

All rights reserved

No part of this book may be reproduced or utilized in any form or by any means,

electronic or mechanical, or by any information storage and retrieval system,

without written permission from the publisher. Please contact Rutgers University Press, 106 Somerset Street, New Brunswick, NJ 08901. The only exception to this prohibition is "fair use" as defined by U.S. copyright law.

(2) The paper used in this publication meets the requirements of the American National Standard for Information Sciences-Permanence of Paper for Printed Library Materials,

ANSI Z39.48-1992.

www.rutgersuniversitypress.org

Manufactured in the United States of America 
Dedicated to all the films that did not get made in the 1970 s and to all the women who tried their best to direct them. 
